\title{
PELATIHAN SKILL KEWIRAUSAHAAN SANTRI MELALUI PEMBUATAN OLAHAN TAHU WALIK DI PONDOK PESANTREN TAHFIDZUL QUR'AN AL-MUQORROBIN SIMAN PONOROGO
}

\author{
TRAINING OS STUDENT ENTREPRENEURSHIP SKILL THROUGH THE \\ MANUFACTURING OF TOFU WALIK AT THE AL MUQORROBIN ISLAMIC \\ BOARDING SCHOOL
}

\author{
Umi Miftahul Zanah*, Mughniatul Ilma \\ Institut Agama Islam Negeri Ponorogo \\ Jl. Puspita Jaya, Krajan, Pintu, Kec. Jenangan, Kabupaten Ponorogo, Jawa Timur 63492 \\ *Email: umimiftahulzanah25@gmail.com \\ (Diterima 08-09-2021; Disetujui 24-09-2021)
}

\begin{abstract}
ABSTRAK
Saat ini pondok pesantren bukan hanya sebuah lembaga berlandaskan nilai agama saja, akan tetapi banyak pondok pesantren yang sudah memadukan kurikulum maupun kegiatan modern di dalamnya. Kemampuan berwirausaha misalnya, banyak santri jika dilatih dengan baik maka skill kewirausahaan mereka dapat memadai dan mampu bersaing di dunia luar. Seperti hal nya di Pondok Pesantren Tahfidzul Quran Siman Ponorogo meskipun pondok tersebut berlatar belakang pondok tahfidz, akan tetapi kegiatan beserta perturannya mengikuti aktivitas santri kuliah di dalamnya. Karena banyak waktu luang yang terbuang sia-sia pada saat libur kuliah maka dalam pengabdian ini dilaksanakan sebuah pelatihan pembuatan olahan tahu walik untuk meningkatkan skill kewirausahaan santri. Tujuan dari pelatihan ini adalah agar santri memiliki kemampuan berwirausaha yang mumpuni sehingga kegiatan yang semula kurang produktif dapat terealisasi dengan baik. Metode yang digunakan dalam penelitian ini adalah dengan menggunakan metode Asset Based Comunity Development (ABCD) dengan mengenali dan mengembangkan aset yang ada di dalam lingkungan pondok pesantren. Pelatihan ini meliputi kegiatan design logo produk, proses produksi serta pemasaran yang dilakukan secara offline maupun online yang dilakukan secara mandiri oleh para santri. Antusias santri yang tinggi dalam mengikuti kegiatan pelatihan, membuat kegiatan ini dapat berjalan dengan baik dan lancar sehingga tujuan yang diharapkan dapat tercapai.
\end{abstract}

Kata kunci : skill kewirausahaan, olahan tahu walik, pondok pesantren

\begin{abstract}
Currently, Islamic boarding schools are not only institutions based on religious values, but many Islamic boarding schools have integrated curricula and modern activities in them. Entrepreneurial ability, for example, if many students are trained properly, their entrepreneurial skills are adequate and can compete in the outside world. As is the case at the Siman Ponorogo Tahfidzul Quran Islamic Boarding School, even though the cottage is a Tahfidz cottage background, the activities and regulations follow the activities of the students studying in it. Because a lot of free time is wasted during college holidays, in this service a training on making processed tofu walik is carried out to improve the entrepreneurial skills of students. The purpose of this training is for students to have good entrepreneurial skills so that activities that were originally less productive can be realized properly. The method used in this study is to use the Asset Based Community Development (ABCD) method by recognizing and developing assets that exist within the Islamic boarding school environment. This training includes product logo design activities, production and marketing processes that are carried out offline and online which are carried out independently by the students. The high enthusiasm of students in participating in training activities makes this activity run well and smoothly so that the expected goals can be achieved.
\end{abstract}

Keywords: entrepreneurial skills, processed tofu walik, Islamic boarding school 
Pelatihan Skill Kewirausahaan Santri Melalui Pembuatan Olahan Tahu Walik Di Pondok Pesantren Tahfidzul Qur'an Al-

\section{PENDAHULUAN}

Kemampuan berwirausaha perlu ditanamkan di semua lingkungan, tak terkecuali pondok pesantren. Menurut Peter F. Ducker, kemampuan untuk menciptakan sesuatu yang baru dan berbeda merupakan pengertian dari wirausaha. Hal ini dapat dinyatakan bahwa hal terpenting dalam bagian ini adalah pelatihan dalam bentuk kegiatan ekonomi dan kewirausahaan dapat meningkatkan nilai strategis bagi pondok pesantren melalui pengembangan skill, wawasan dan keterampilan para santri. Pengembangan life skill sudah ada sejak pondok pesantren tersebut berdiri dan mengalami perkembangan pesat hingga saat ini (Nihro Afanndi, 2019). Akan tetapi masih terdapat beberapa pondok dimana kondisi skill kewirausahaan santri masih kurang. Salah satunya santri di PPTQ Al Muqorrobin, kemampuan berwirausaha mereka masih kurang. Waktu luang yang mereka miliki pada saat liburan membuat para santri kurang melakukan hal produktif karena penggunaan handphone dan akses untuk keluar pondok dibatasi sejak pandemi covid 19 ini.

Pengabdian yang dilaksanakan di pondok pesantren ini adalah dengan memanfaatkan aset dan potensi yang ada. Para santri akan dilatih skill kewirausahaannya melalui pembuatan olahan tahu walik yang kekinian, dikemas dengan berbagai rasa sehingga menarik dan tentunya memiliki harga jual yang tinggi. Mereka akan dilibatkan secara langsung mulai dari proses design, produksi hingga pemasaran. Hal tersebut merupakan salah satu kegaiatan yang dapat digunakan untuk mengembangkan keterampilan para santri di pondok pesantren dalam mengisi waktu luang mereka. Pengembangan keterampilan dengan memanfaatkan aset dan potensi yang dimiliki masyarakat dapat meningkatkan perekonomian masyarakat (Aprilia, 2018). Dalam penelitian ini pelatihan yang dilakukan untuk santri merupakan sebuah kegiatan yang bertujuan untuk mengembangkan kemampuan santri dalam bidang keterampilan wirausaha. Kewirausahaan atau entrepreneurship adalah usaha kreatif yang dibangun berdasarkan inovasi untuk menghasilkan sesuatu yang baru, memiliki nilai tambah, memberi manfaat, menciptakan lapangan kerja dan hasilnya berguna bagi orang lain (Andhy Tri, 2020). Dengan adanya kemampuan yang mereka miliki akan dapat memberikan manfaat terhadap potensi yang belum mereka kembangkan seperti memproduksi dan memasarkan suatu produk. Pasalnya di era modern seperti saat ini teknologi dalam memasarkan produk juga dapat dilakukan secara online. 
Sejauh ini kegiatan pengabdian mengenai pelatihan yang melibatkan santri dalam membuat inovasi olahan pangan mungkin jarang dijumpai. Berikut beberapa artikel kegiatan pengabdian yang dilakukan oleh Nur Asizah dkk yang berjudul "Pemberdayaan, Ibu Rumah Tangga Kelompok Industri Tahu Berbasis Produk Aneka Olahan Tahu Untuk Meningkatkan Pendaptan Keluarga di Masa Pandemi Covid-19 di Desa Lambusa Kabupaten Konawe Selatan” penelitian ini menggunakan objek ibu-ibu rumah tangga dan berfokus pada pelatihan dalam menghasilkan produk siap saji juga frozen food, serta memberikan pelatihan meliputi praktek pembuatan secara individu dan kelompok praktek pengemasan, pemasaran online produk frozen food melalui marketing channel secara online. Selanjutnya artikel pengabdian oleh Rumanintya Lisaria Putri dan Diana Elvianita Martanti dalam jurnalnya yang berjudul "Pemberdayaan Usaha Ekonomi Produktif Bagi Masyarakat di Kelurahan Kepanjen Lor Kota Blitar Dalam Pelatihan Pembuatan Keripik Pepaya" menyatakan bahwa mereka melakukan penelitian dengan melakukan pelatihan kepada masyarakat dengan tujuan agar mereka dapat membuat berbagai olahan dengan bahan dasar pepaya dengan mandiri sehingga dapat disajikan sebagai camilan keluarga serta dapat digunakan untuk membuka peluang usaha. Pengabdian lainnya oleh Ayunda Riska Puspita dengan judul "Pemanfaatan Limbah Tahu Sebagai Upaya Meningkatkan Perekonomian Masyarakat Desa Bringinan, Kecamatan Jambon, Ponorogo” penelitian ini berisi tentang pendampingan dalam pengolahan limbah tahu yang ada di lingkungan sekitar yang diolah menjadi kripik ampas tahu yang bernilai jual tinggi. Penelitian ini bertujuan untuk mengurangi jumlah TKW di Desa Bringinan serta meningkatkan perekonomian ibu-ibu PKK Desa Bringinan. Dalam artikel di atas, sasaran pengabdiannya mayoritas adalah masyarakat, dan tujuan penelitiannya adalah untuk mengembangkan perekonomian dan peluang usaha bagi masyarakat. Untuk itu, pengabdian di PPTQ Al Muqorrobin ini menjadikan santri sebagai subjek sasarannya agar waktu luang mereka dapat terisi dengan kegiatan produktif.

Olahan tahu walik ini merupakan inovasi pertama yang dilakukan santri PPTQ Al Muqorrobin guna mengembangkan skill kewirausahaan dalam lingkungan pondok. Pelatihan ini bertujuan untuk menciptakan serta mengembangkan skill kewirausahaan santri dalam membuat sebuah inovasi olahan baru yang akan memberikan manfaat banyak baik bagi diri mereka sendiri maupun lingkungan sekitar. Oleh karena itu, penulis merasa sangat perlu untuk melakukan pelatihan pembuatan olahan tahu walik agar skill kewirausahaan santri dapat tercapai sesuai dengan tujuan dari program pengabdian. Selain itu, penulis juga berharap agar pengabdian ini dapat mengembangkan keterampilan santri 
Pelatihan Skill Kewirausahaan Santri Melalui Pembuatan Olahan Tahu Walik Di Pondok Pesantren Tahfidzul Qur'an Al-

serta mampu meningkatakan produktifitas mereka dalam membangun sebuah inovasi usaha di PPTQ Al Muqorrobin dan juga para santri mampu mengetahui serta memanfaatkan aset yang dimiliki sehingga menjadikan kegiatan lebih produktif lagi dan memberikan perubahan baik yang dapat bermanfaat bagi diri sendiri maupun lingkungan sekitar pondok pesantren.

\section{BAHAN DAN METODE}

Kegiatan pengabdian masyarakat ini berlangsung selama kurang lebih satu bulan penuh mulai dari tanggal 5 Juli 2021 sampai dengan 13 Agustus 2021 yang berlokasi di PPTQ Al Muqorrobin Siman Ponorogo. Dalam pelaksanaan pengabdian ini menggunakan metode ABCD (Asset Based Community Development) yang merupakan sebuah metode untuk meningkatkan kemajuan para individu dengan berlandaskan aset lokal yang terdapat dalam suatu wilayah. Pelaksanaan pelatihan santri ini menggunakan pendekatan ABCD (Asset Based Community Development) yang mengutamakan pemanfaatan aset dan potensi yang ada di sekitar lingkungan pondok pesantren yang dimiliki oleh santri. Salah satu tujuan pendekatan ini adalah menggali aset yang dimiliki dalam suatu wilayah. Dalam lingkungan pondok pesantren sendiri, salah satu aset yang dapat dikembangkan adalah skill kewirausahaan para santri. Skill kewirausahaan santri dapat dikembangkan melalui pelatihan membuat suatu inovasi produk yang diolah dan dikelola oleh santri secara mandiri.

Dalam pelatihan ini pihak yang dilibatkan adalah beberapa santri yang berjumlah kurang lebih 4-5 orang. Lokasi pengabdian adalah di PPTQ Al Muqorrobin karena lokasi dipilih karena strategis dengan rumah produksi tahu juga mayoritas santri memiliki antusias yang sangat tinggi terhadap program yang akan dilakukan sehingga proses pelaksanaan pelatihan skill kewirausahaan dapat berjalan lancar sesuai tujuan. Adapun penerapan metode $\mathrm{ABCD}$ mempunyai beberapa langkah kunci dalam pelaksanaan proses riset pendampingan di antaranya (Christopher Dureau: 96-97) :

\section{Discovery (Menemukan)}

Discovery merupakan tahap awal dalam proses pengabdian sehingga dapat diartikan bahwa kegiatan dalam proses ini berupa wawancara maupun percakapan mengenai apa yang menjadi kontribusi dalam sebuah kegiatan atau usaha. Dalam tahap ini sudah mulai menggali aset apa saja yang terdapat di Pondok Pesantren Tahfidzul Quran Al Muqorrobin. Dalam prespektif ABCD aset merupakan sesuatu yang memiliki potensi dan dapat dikembangkan sehingga memberikan perubahan yang baik. Perubahan itu 
sendiri dapat diwujudkan melalui keikutsertaan para santri PPTQ Al Muqorrobin dalam proses langsung di lapangan. Selain melibatkan santri dalam melakukan prosesnya penemukenalan dilakukan kepada para pengurus PPTQ Al Muqorrobin yaitu lurah dan $\mathrm{CO}$ dapur terkait perizinan proses pengabdian di dalam lingkungan pondok.

2. Dream (Mimpi)

Melalui cara yang kolektif dan inovatif dengan optimis ke masa depan yang akan terwujud, apa yang akan terjadi harus dihubungkan dengan yang sangat diinginkan. Tahapan ini setiap individu mengksplorasi impian dan harapan mereka baik untuk orang lain maupun untuk dirinya sendiri. Pada proses ini, setiap santri mengeksplorasi harapan serta impian mereka baik untuk diri sendiri maupun lingkungan pondok. Dari banyaknya aset di PPTQ Al Muqorrobin, maka dipilih skill kewirausahaan santri yang masih sangat kurang, maka dari itu dihadirkan pelatihan berupa inovasi pembuatan tahu walik yang bahan dasar tahu nya diambil dari rumah produksi sekitar pondok.

3. Design (Merancang)

Tahap ini merupakan proses di mana seluruh komunitas atau kelompok terlibat dalam proses belajar tentang kekuatan atau aset yang dimiliki agar bisa mulai memanfaatkannya dalam; cara yang konstruktif, inklusif, dan kolaboratif untuk mencapai aspirasi dan tujuan seperti yang sudah ditetapkan sendiri. Proses merancang ini merupakan cara untuk menetahui aset yang ada pada santri PPTQ Al Muqorrobin. Aset yang akan dimanfaatkan adalah skill wirausaha para santri melalui pembutan olahan tahu walik di PPTQ Al Muqorrobin

4. Define (Menentukan)

Pada tahap ini bisa disebut dengan istilah proses pencarian atau deskripsi tentang perubahan yang diinginkan. Hal yang dibahas dalam tahap ini adalah hal hal yang positif serta mendukung terlaksananya program. Pendampingan bersama santri terlibat dalam FGD (Focus Group Discussion). Pada proses ini pendamping dan para santri diskusi dan menentukan fokus pembahasan meliputi proses pembuatan design logo, produksi, pengemasan dan pemasaran olahan tahu walik.

5. Destiny (Melakukan)

Segala kegiatan inspiratif yang dapat mendukung terlaksananya program secara terus menerus serta sebuah inovasi terkait "hal apa yang akan terjadi". Tahap ini merupakan step terakhir untuk memenhui impian para santri dari pemanfaatan aset. Selain untuk memenuhi impian santri dalam mengembangkan skill kewirausahaan mereka, kegiatan ini dapat memberikan ruang produktif bagi para santri serta dapat meningkatkan 
Pelatihan Skill Kewirausahaan Santri Melalui Pembuatan Olahan Tahu Walik Di Pondok Pesantren Tahfidzul Qur'an Al-

ekonomi pondok pesantren. Berikut merupakan model pelatihan skill kewirausahaan santri di PPTQ Al Muqorrobin.

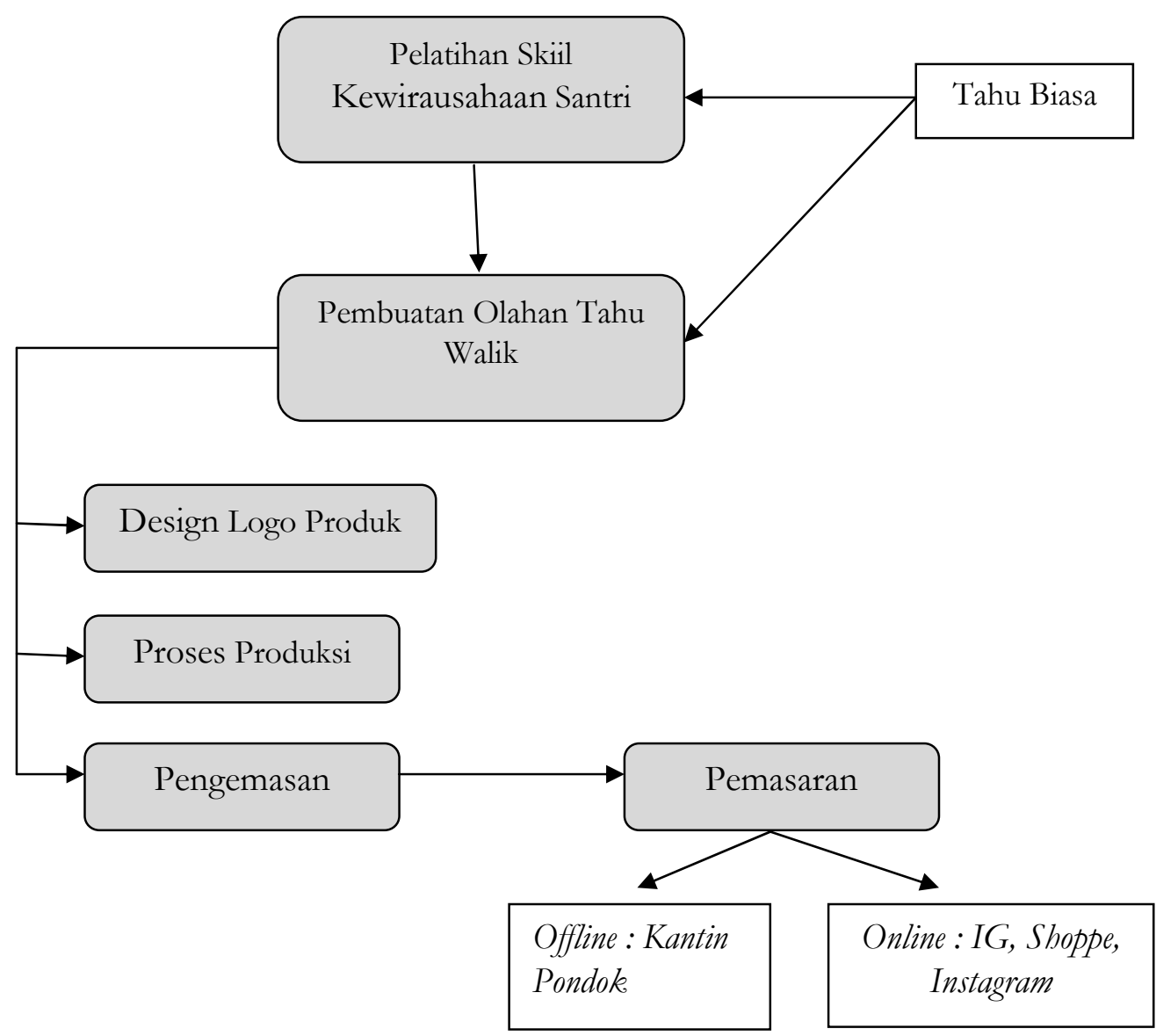

Gambar 1. Model Pelatihan Pembuatan Olahan Tahu Walik

Berdasarkan model di atas dapat diketahui bahwa selain fokus pada pengolahan atau proses produksi, pelatihan ini juga fokus pada pembuatan design logo serta pemasaran yang dilakukan baik secara online maupun offline

\section{HASIL DAN PEMBAHASAN}

Pelatihan dimulai dari pendampingan pembentukan kelompok produksi, sosialisasi pembuatan tahu walik, pelatihan design logo dan pengemasan, monitoring dan controlling proses produksi serta pemasaran yang dilakukan via offline maupun online. Pelatihan ini merupakan kegiatan yang dilakukan secara berkelanjutan yang tidak berhenti pada proses produksi saja, akan tetapi para santri juga dilatih sampai tahap pemasaran online di media sosial. Berikut merupakan bentuk kegiatan dalam proses pelatihan skiill kewirausahaan santri PPTQ Al-Muqorrobin: 


\section{A. Pembentukan Forum Group Discussion}

Kondisi pandemi yang masih berlangsung, juga PPKM yang terus diperpanjang, maka peserta yang mengikuti pelatihan ini dibatasi hanya 4-5 santri saja. Sebelum memasuki tahap awal pelaksanaan para santri diberi angket untuk mengetahui seberapa jauh pengetahuan mereka tentang kewirausahaan pembuatan olahan tahu walik. Setelah selesai mengisi angket, para santri disosialisasi terkait pembuatan olahan ini. Sosialisasi pembuatan tahu walik ini dimulai dari pembentukan forum group disscussion yang diikuti beberapa santri yang terlibat dalam proses produksi tahu walik. Penanggung jawab dalam kegiatan produksi ini adalah penulis sendiri sebagai pelaksana kegiatan pengabdian diikuti beberapa santri yang sudah dibagi sesuai dengan bagian mereka masing-masing. Berikut merupakan struktur kelompok produksi tahu walik santri.

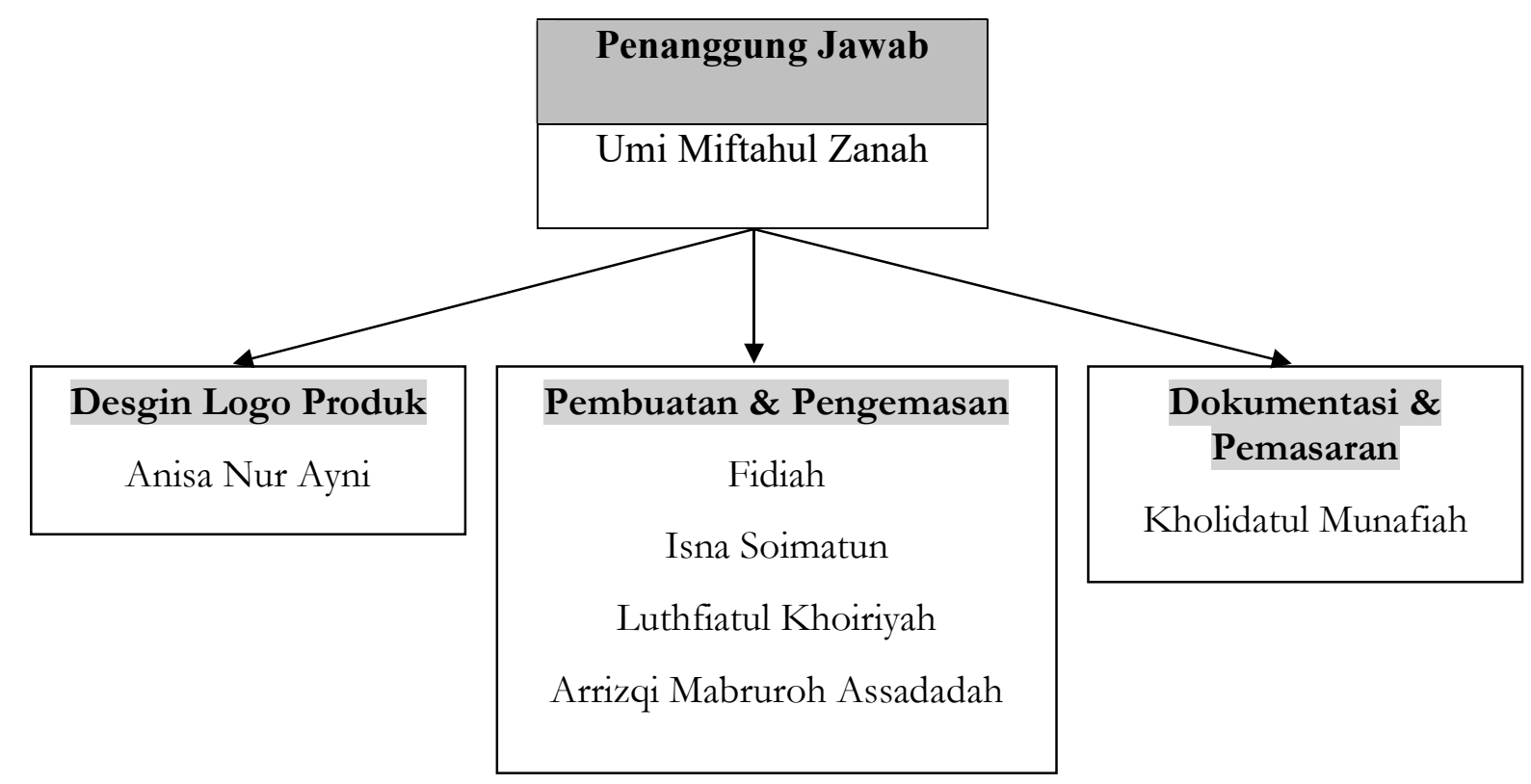

Gambar 2. Struktur Kelompok Pelatihan Olahan Tahu Walik

\section{B. Proses Produksi Olahan Tahu Walik}

Setelah selesai pembentukan struktur kelompok produksi tahu walik santri, kegiatan selanjutnya adalah sosialisasi proses pembuatan tahu walik. Alat dan bahan yang digunakan dalam proses pembuatan olahan ini adalah sebagai berikut:

1. Wajan dan seperangkatnya

2. Wadah besar

3. Tahu yang sudah digoreng

4. Penyedap rasa

5. Merica/ladaku

6. Garam 
Pelatihan Skill Kewirausahaan Santri Melalui Pembuatan Olahan Tahu Walik Di Pondok Pesantren Tahfidzul Qur'an Al-

\section{Minyak goreng}

8. Bumbu balado

Setelah sosialisasi terkait alat dan bahan yang dibutuhkan, maka lanjut sosialiasi langkah-langkah proses pembuatan tahu walik. Proses pembuatan tahu walik dilaksanakan pada tanggal 28 Juli 2021 mulai pukul sekitar pukul $10.00 \mathrm{~s} / \mathrm{d} 12.30$ di dapur pondok pesantren. Langkah-langkah pembuatannya adalah sebagai berikut:

1. Siapkan tahu yang sudah digoreng

2. Potong tahu menjadi dua bagian

3. Balik setiap bagian tahu secara keseluruhan

4. Setelah itu, campurkan tahu tersebut dengan bumbu yang sudah tersedia hingga rata

5. Panaskan minyak goreng

6. Masukkan tahu yang sudah diberi bumbu tersebut sedikit demi sedikit ke minyak yang sudah dipanaskan

7. Angkat dan tiriskan tahu jika sudah matang

8. Campur sebagian tahu dengan bumbu balado hingga rata

9. Pisahkan antara tahu dengan rasa original dan rasa balado ke dalam wadah yang berbeda

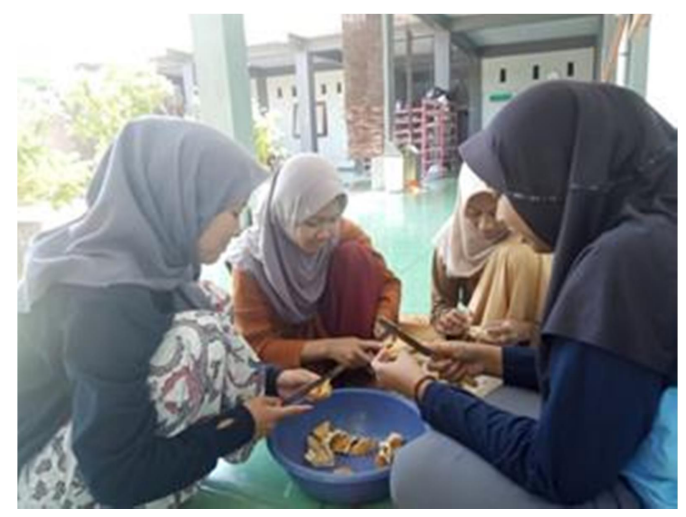

Gambar 3. Proses Pembuatan Tahu Walik

Pemberian varian rasa yang berbeda yaitu original dan balado digunakan agar olahan tahu walik ini memiliki cita rasa yang bervariasi sehingga dapat menarik customer. Sasaran konsumen yang bermacam-macam dari segala umur dengan berbagai selera membuat olahan ini harus dibuat dengan berbagai macam rasa yang berbeda.

Modal yang digunakan dalam pelatihan skill kewirausahaan santri melalui proses pembuatan tahu walik ini dapat dikatakan terjangkau serta memiliki nilai jual yang tinggi, 
pasalnya dalam satu kali produksi tahu walik ini memiliki laba bersih sekitar Rp 25.000. Untuk estimasi biaya yang dibutuhkan adalah sebagaimana tersaji pada Tabel 1 .

Tabel 1. Estimasi Biaya Produksi Pembuatan Tahu Walik

\begin{tabular}{lc}
\multicolumn{1}{c}{ Nama Bahan } & Harga \\
\hline Tahu goreng $1 \mathrm{~kg}$ & $\mathrm{Rp} 25.000$ \\
Penyedap rasa (Royco 2 bungkus) & $\mathrm{Rp} 1000$ \\
Merica bubuk (Ladaku 1 bungkus) & $\mathrm{Rp} 1000$ \\
Minyak goreng & $\mathrm{Rp} 6000$ \\
Bumbu balado & $\mathrm{Rp} \mathrm{5000}$ \\
Stiker logo 1 lembar ( 50 stiker) & $\mathrm{Rp} \mathrm{5000}$ \\
Standing pouch (25 pcs) & $\mathrm{Rp} \mathrm{7000}$ \\
\hline Total Pengeluaran produksi & $\mathrm{Rp} \mathrm{50.000}$ \\
\hline
\end{tabular}

Dengan biaya $\mathrm{Rp} 50.000$ untuk sekali proses pembuatan, dengan bahan dasar tahu goreng sebesar $1 \mathrm{~kg}$ dapat terjual tahu walik sebanyak 25 pcs dengan total harga $\mathrm{Rp}$ 75.000. Laba bersih yang diperoleh santri untuk sekali pembuatan tahu walik adalah sekitar Rp 25.000. Rincian perolehan laba bersih pembuatan tahu walik tersaji pada Tabel 2.

Tabel 2. Pendapatan Hasil Produksi Pembuatan Tahu Walik

\begin{tabular}{ll}
\hline \multicolumn{2}{c}{ Estimasi penjualan adalah 25 bungkus } \\
\hline Biaya total satu kali produksi & $\mathrm{Rp} 50.000$ \\
Harga per pcs & $\mathrm{Rp} 50.000: 25 \mathrm{pcs}=\mathrm{Rp} 2000$ \\
Harga jual & $\mathrm{Rp} 3000$ \\
Biaya total penjualan & $\mathrm{Rp} 3000 \times 25 \mathrm{pcs}=\mathrm{Rp} 75.000$ \\
Laba kotor & $\mathrm{Rp} 75.000-\mathrm{Rp} 50.000$ \\
Laba bersih & $\mathrm{Rp} 25.000$ \\
\hline
\end{tabular}

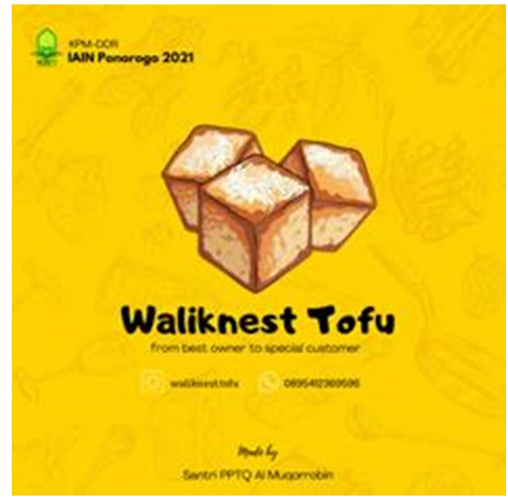

Gambar 4. Hasil Design Logo Produk Olahan Tahu Walik

Selain dengan menggunakan stiker logo di atas, pemilihan plastik yang digunakan untuk mengemas produk adalah plastik standing pouch ukuran 10 x $17 \mathrm{~cm}$. Alasan memilih plastik jenis ini adalah tingkat keamanan yang tinggi (rapat) sehingga kualitas tahu walik yang ada di dalamnya dapat terjaga ke krispy annya. Gambar 5 merupakan hasil akhir produk yang sudah dikemas dan diberi label sehingga produk siap dipasarkan. 
Pelatihan Skill Kewirausahaan Santri Melalui Pembuatan Olahan Tahu Walik Di Pondok Pesantren Tahfidzul Qur'an AlMuqorrobin Siman Ponorogo

Umi Miftahul Zanah, Mughniatul Ilma

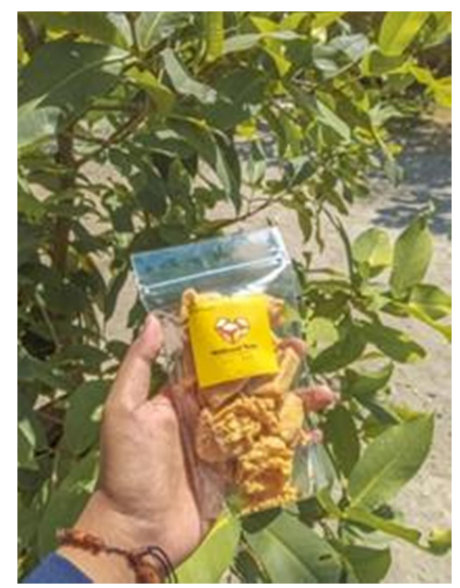

Gambar 5. Hasil Olahan Tahu Walik Yang Siap Dipasarkan

\section{Pemasaran Produk Olahan Tahu Walik Via Offline Maupun Online}

Setelah proses packing selesai, proses akhir dari tahap pelatihan skill kewirausahaan santri ini adalah proses pemasaran. Pemasaran dilakukan dengan dua cara, yaitu secara offline yang dilakukan dengan dititipkan di kantin pondok, dan secara online yang dilakukan melalui promosi di media sosial facebook, shoppee dan instagram. Pemasaran yang dilakukan secara online dipilih agar inovasi produk usaha yang dibuat para santri dapat dikenal oleh masyarakat luas, bukan hanya terbatas di lingkungan pondok pesantren saja. Berikut merupakan contoh pemasaran yang dilakukan secara online melalui media sosial.
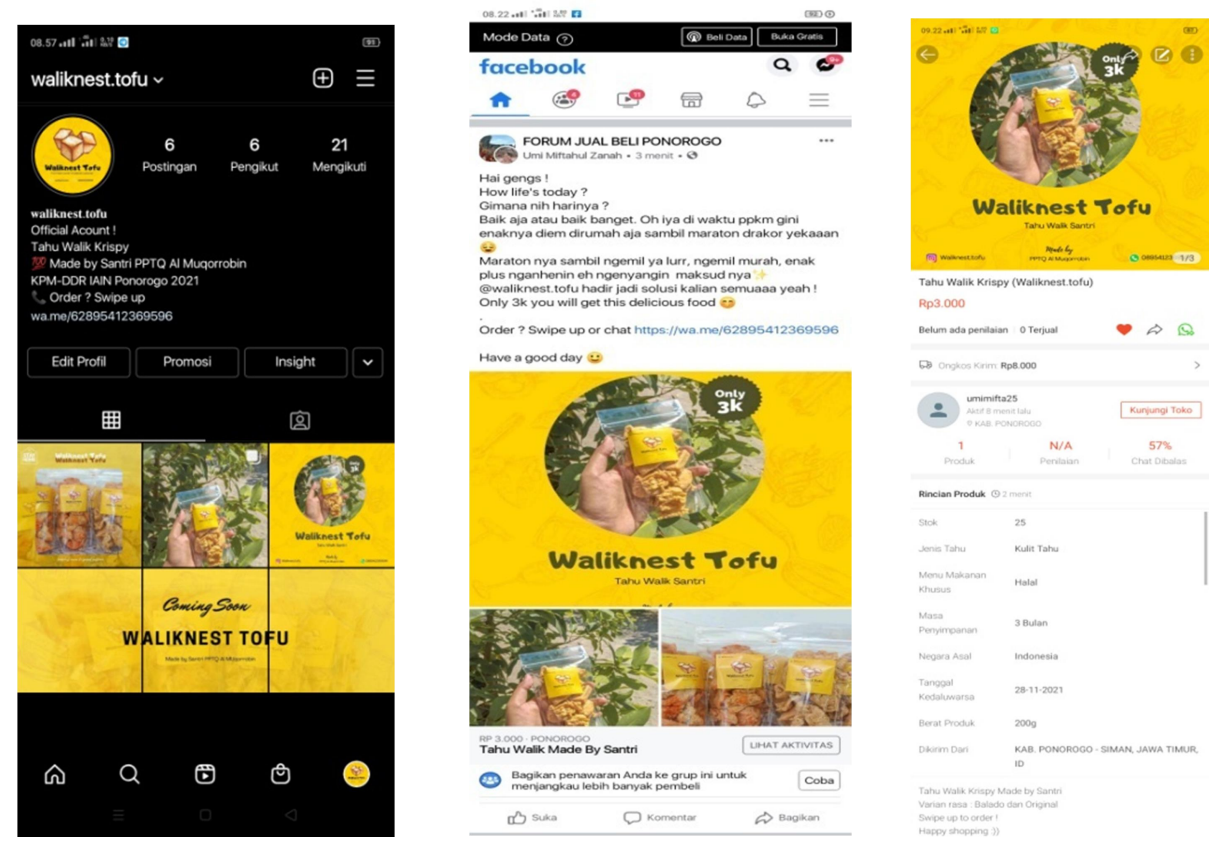

Gambar 6. Pemasaran Online Melalui Instagram, Facebook dan Shoppee 


\section{Evaluasi Pelaksanaan Pelatihan}

Melalui pelatihan pembuatan olahan tahu walik ini, skill kewirausahaan santri yang dulunya belum berkembang dengan baik dapat meningkat sehingga memberikan dampak yang positif baik untuk dirinya sendiri maupun untuk lingkungan pondok pesantren. Pelaksanaan kegiatan ini dibutuhkan evaluasi untuk mengetahui keberhasilan pelatihan ditinjau dari pemahaman santri mengenai skill kewirausahaan mereka sebelum dan sesudah mengikuti pelatihan pembuatan olahan tahu walik. Evaluasi pemahaman santri dilakukan melalui pemberian angket pre test dan pos test. Angket pre test diberikan sebelum kegiatan pelatihan dilaksanakan sedangkan angket post test diberikan setelah kegiatan dilaksanakan. Hal tersebut diperlukan untuk meningkatkan layanan pada kegiatan pengabdian sejenis (Ahmad Natsir dkk: 2020). Skill kewirausahaan santri diketahui setelah proses keseluruhan pelatihan ini dilaksanakan. Mulai dari kegiatan design logo hingga ke tahap pemasaran baik offline maupun online. Karena kondisi sedang PPKM maka jumlah santri yang diajak untuk mengikuti pelatihan dibatasai hanya 5 orang santri. Berikut merupakan angket pelatihan skill kewirausahaan santri melalui pembuatan olahan tahu walik di PPTQ Al Muqorrobin.

\begin{tabular}{|c|c|c|c|c|c|}
\hline \multirow{2}{*}{ No } & \multirow{2}{*}{ Pertanyaan } & \multicolumn{2}{|c|}{ Pre Test } & \multicolumn{2}{|c|}{ Post Test } \\
\hline & & Ya & Tidak & Ya & Tidak \\
\hline 1. & $\begin{array}{l}\text { Saya pernah mengikuti pelatihan skill kewirausahaan } \\
\text { sebelumnya }\end{array}$ & $20 \%$ & $80 \%$ & $100 \%$ & - \\
\hline 2. & Saya tahu tentang olahan tahu walik & $40 \%$ & $60 \%$ & $100 \%$ & - \\
\hline 3. & Saya pernah membuat olahan tahu walik & $20 \%$ & $80 \%$ & $100 \%$ & - \\
\hline 4. & Saya tahu cara pembuatan olahan tahu walik & $40 \%$ & $60 \%$ & $100 \%$ & - \\
\hline 5. & Saya tahu resep pembuatan olahan tahu walik & - & $100 \%$ & $100 \%$ & - \\
\hline 6. & $\begin{array}{l}\text { Saya bisa design logo produk sendiri secara } \\
\text { sederhana }\end{array}$ & - & $100 \%$ & $80 \%$ & $20 \%$ \\
\hline 7. & $\begin{array}{l}\text { Saya dapat memasarkan produk secara online } \\
\text { melalui media sosial }\end{array}$ & $40 \%$ & $60 \%$ & $80 \%$ & $20 \%$ \\
\hline 8. & $\begin{array}{l}\text { Saya tahu kendala apa saja dalam proses produksi } \\
\text { tahu walik di pondok pesantren }\end{array}$ & - & $100 \%$ & $100 \%$ & - \\
\hline 9. & $\begin{array}{l}\text { Saya rasa olahan tahu walik mudah dibuat secara } \\
\text { mandiri }\end{array}$ & $20 \%$ & $80 \%$ & $80 \%$ & $20 \%$ \\
\hline 10. & $\begin{array}{l}\text { Saya berfikir olahan tahu walik mempunyai nilai jual } \\
\text { yang tinggi }\end{array}$ & $20 \%$ & $80 \%$ & $100 \%$ & - \\
\hline
\end{tabular}

Dari data Tabel 3 dapat diketahui bahwa secara umum pemahaman skill kewirausahaan santri sebelum dilaksanakannya pelatihan $80 \%$ santri belum memiliki skill kewirausahaan. Hanya 20\% santri yang sudah paham mengenai kewirausahaan dalam inovasi pembuatan olahan suatu produk. Persentase di atas jauh berbeda setelah pelatihan 
Pelatihan Skill Kewirausahaan Santri Melalui Pembuatan Olahan Tahu Walik Di Pondok Pesantren Tahfidzul Qur'an Al-

pembuatan olahan tahu walik yang dilaksanakan dalam pondok, hanya sekitar 1\% santri yang menyatakan belum paham mengenai pembuatan olahan tahu walik ini, sisanya sebanyak 99\% santri sudah berhasil memahami proses produksi serta pemasaran olahan tahu walik ini.

Hasil evaluasi terhadap pelaksanaan pelatihan ini menunjukkan bahwa secara umum para santri yang mengikuti pelatihan sudah paham serta memiliki skill kewirauasahan yang memadai, baik dalam segi design logo produk, proses serta pemasaran dengan media sosial. Antusias para santri dalam mengikuti pelatihan juga sangat tinggi sehingga kemampuan mereka dalam berwirausaha mengalami peningkatan. Waktu luang yang biasanya tidak terkodinir dengan baik setelah adanya pelatihan ini, para santri mendapat kegiatan yang lebih produktif, perekonomian pondok pesantren mengalami peningkatan serta inovasi usaha di dalam pondok pesantren dapat dikelola dan dikembangkan secara mandiri oleh para santri.

Berdasarkan evaluasi pelaksanaan dan hasil kegiatan pelatihan dapat diidentifikasi faktor pendukung dan penghambat dalam melaksanakan program pengabdian masyarakat (Salmiati dkk, 2018). Beberapa faktor tersebut adalah sebagai berikut:

1. Faktor Pendukung Kegiatan Pelatihan

a. Dukungan dari ketua pondok pesantren terhdap kegiatan pelatihan skill kewirausahaan santri melalui pembuatan olahan tahu walik di lingkungan pondok pesantren.

b. Ketersediaan tempat dan kelengkapan peralatan dapur sebagai penunjang keberhasilan kegaiatan proses produksi.

c. Ketersediaan dana pendukung dari pengurus pondok sebagai pendukung penyelenggaraan kegiatan pelatihan pembuatan olahan tahu walik.

d. Antusiasme santri yang tinggi dalam proses pelatihan skill kewirausahaan melalui pembuatan olahan tahu walik dalam lingkungan pondok pesantren.

2. Faktor Penghambat Kegiatan Pelatihan

a. Keterbatasan waktu yang dimiliki santri, karena pelatihan ini merupakan kegiatan sampingan untuk mengisi waktu luang santri, oleh karena itu kegiatan produksi tidak dapat dilakukan secara full time dan hanya bisa menyesuaikan waktu luang santri.

b. Keterbatasan penggunaan handphone, akibatnya pemasaran yang dilakukan secara online tidak dapat dilakukan dengan fast respon sehingga proses pemasaran dilakukan hanya mengikuti jam buka hp/online santri. 
Berdasarkan hasil pelatihan di atas, meskipun terdapat sedikit kendala akan tetapi pelaksanaan kegaiatan pengabdian dengan judul "Pelatihan Skill Kewirausahaan Santri Melalui Pembuatan Olahan Tahu Walik di Pondok Pesantren Tahfidzul Quran Siman Ponorogo" telah memberikan dampak yang positif bagi para santri maupun bagi pondok pesantren sehingga kegiatan pengabdian ini dapat dikatakan berhasil dan dinilai dengan baik.

\section{KESIMPULAN DAN SARAN}

Program pelaksanaan pengabdian yang dilakukan di Pondok Pesantren Tahfidzul Quran Al Muqorrobin Siman Ponorogo merupakan sebuah kegiatan berupa pelatihan skill kewirausahaan santri melalui pembuatan olahan tahu walik. Metode yang digunakan dalam program pengabdian ini adalah metode $\mathrm{ABCD}$ (Aset Based Comunity Development) yang memanfaatkan aset serta potensi yang dimiliki lingkungan pondok pesantren untuk dikembangkan. Potensi yang dapat dikembangkan di Pondok Pesantren Tahfidzul Quran Al Muqorrobin Siman Ponorogo adalah skill kewirausahaan para santri yang masih sangat minim, oleh karena itu dalam pelaksanaan pengabdian ini diadakan sebuah pelatihan untuk meningkatkan skill kewirausahaan santri.

Berdasarkan kegiatan pelatihan skill kewirausahaan santri tersebut yang meliputi kegiatan pelatihan design logo, proses pembuatan serta pemasaran dilakukan secara mandiri oleh santri berjalan dengan lancar. Melalui pelatihan ini skill kewirausahaan santri bisa berkembang dengan memanfaatkan waktu luang mereka yang kurang produktif sebelumnya. Selain itu, pelatihan ini dapat meningkatkan perekonomian pondok pesantren melalui inovasi pembuatan olahan tahu walik yang murah tapi berharga jual tinggi yang dibuat dan dikelola secara mandiri oleh para santri. Pemasaran yang dilakukan secara online dapat membantu produk ini dikenal oleh masyarakat luas bukan hanya terbatas di sekitar pondok pesantren. Meskipun kegiatan pengabdian ini sudah selesai, inovasi olahan yang dibuat santri ini harus dikembangkan lagi bisa dengan jenis olahan yang berbeda, skill kewirausahaan yang mereka punya setelah mengikuti pelatihan ini dapat dimanfaatkan agar produksi yang dilakakukan dapat berkembang dengan skala besar sehingga dapat menciptakan kegiatan produktif bagi para santri lainnya.

\section{UCAPAN TERIMA KASIH}

Penulis mengucapkan terima kasih Ibu Mughniatul Ilma selaku dosen pembimbing lapangan kelompok 64 KPM DDR IAIN Ponorogo yang telah membimbing dan 
Pelatihan Skill Kewirausahaan Santri Melalui Pembuatan Olahan Tahu Walik Di Pondok Pesantren Tahfidzul Qur'an Al-

mengarahkan dalam melaksanakan program pengabdian. Selain itu, penulis juga mengucapkan terima kasih kepada seluruh pengurus, serta santriwati PPTQ Al Muqorrobin yang telah berpartisipasi membantu terlaksananya kegiatan pengabdian sehingga dapat berjalan dengan lancar.

\section{DAFTAR PUSTAKA}

Ahmad Natsir, Hawwin Muzakki, And Muchlis Daroini. "Posdaya Berbasis Pesantren: Pelatihan Manajemen Madrasah Dan Pengelolaan Kelas Di Pondok Pesantren Tahfidzul Qur'an 'Hasan Munadi Pohsawit' Ponorogo.' Inej: Indonesian Engagement Journal Vol. 1, No. 2 (2020).

Andhy Tri Adriyanto. "Pemberdayaan Kewirausahaan Ibu-Ibu Rumah Tangga Melalui Pelatihan Pembuatan Berbagai Olahan Pisang Di Kelurahan Panggung Lor.” Jurnal Riptek 14, No. 1 (Agustus 2020).

Aprilia Aimmatul Hidayah. "Pemberdayaan Masyarakat Melalui Inovasi Pengelolaan Kedelai Menjadi Cookies Tempe Untuk Meningkatkan Perekonomian Di Desa Wonoasri Kecamatan Wonoasri Kabupaten Madiun." Universitas Islam Negeri Sunan Ampel Surabaya, April 2018.

Ayunda Riska Puspita. "Pemanfaatan Limbah Tahu Sebagai Upaya Meningkatkan Perekonomian Masyarakat Desa Bringinan, Kecamatan Jambon, Ponorogo” 1, No. 2 (September 2020).

Christopher Dureau. Pembaru Dan Kekuatan Lokal Untuk Pembangunan. Australian Community Development And Civil Society Strengthening Scheme (Access) Tahap Ii, N.D.

Dian Adi Anggraeni Elisabeth. "Pengaruh Pengemasan Dan Pelabelan Pada Penerimaan Mi Kering Berbahan Baku Tepung Komposit Ubi Jalar Dan Keladi." Jurnal Matematika, Saint, Dan Teknologi Vol. 16, No. 2 (September 2017).

Nihro Afandi. "Pengembangan Life Skill Santri Di Pondok Pesantren Mukmin Mandiri Dan Al-Hidayah Sidoarjo (Perspektif Entrepreneurship Islam)." Universitas Islam Negeri Sunan Ampel, 2019.

Nur Asizah. "Pemberdayaan, Ibu Rumah Tangga Kelompok Industri Tahu Berbasis Produk Aneka Olahan Tahu Untuk Meningkatkan Pendaptan Keluarga Di Masa Pandemi Covid-19 Di Desa Lambusa Kabupaten Konawe Selatan.” Jurnal Pengabdian Mayarakat 2, No. 2 (Mei 2021).

Rumanintya Lisaria Putri And Diana Elvianita Martanti. "Pemberdayaan Usaha Ekonomi Produktif Bagi Masyarakat Di Kelurahan Kepanjen Lor Kota Blitar Dalam Pelatihan Pembuatan Keripik Pepaya" 1, No. 1 (April 2019).

Salmiati, Hasbahuddin, And Muhammad Ilham Bakhtiar. 2018. "Pelatihan Konselor Sebaya Sebagai Strategi Pemecahan Masalah Siswa." Jurnal Pengabdian Kepada Masyarakat Vol. 1, No. 1 (N.D.).

Septiyarani Hidayati. "Pelatihan Kewirausahaan Di Pondok Pesantren Putri Taruna AlQur'an Yogyakarta Sebagai Wadah Pengembangan Potensi Santri." Jurnal Pendidikan Sosiologi 1 (N.D.). 